\title{
PEMBERDAYAAN EKONOMI PESANTREN MELALUI PENGELOLAAN SAMPAH DAN BARANG BEKAS DI PONDOK PESANTREN MADRASATUL QUR'ANIYYAH SENTELUK
}

\author{
Lalu Muchsin Effendi \\ Institut Agama Islam Negeri Mataram \\ E-mail: fl.madjdi@yahoo.co.id
}

\begin{abstract}
Abstrak: Pengabdian di Madrasatul Qu'aniyyah Senteluk Lombok Barat dalam bentuk pendampingan dan pelatihan ini bertujuan untuk meningkatkan kualitas pendidikan Non Formal sebagai upaya peningkatan pengetahuan bagi pengasuh dan kesadaran para santri/siswa-siswi tentang pentingnya kreativitas dan keterampilan untuk bersaing di era globalisasi. Melihat kondisi buruknya penanganan dan pengelolaan sampah dan barang bekas, maka perlu dilakukan pendampingan dalam bentuk pelatihan untuk peningkatan kualitas Sumber Daya Manusia (SDM). Peningkatan kualitas SDM yang dimulai sejak dini dapat berpengaruh pada daya saing individu itu sendiri. Langkah yang diambil adalah dengan memberikan keterampilan tambahan kepada para santri kelas III Madrasah Aliyah yang berusia produktif. Salah satu keterampilan yang harus diberikan kepada santri/siswa adalah keterampilan mengelola sampah dan barang bekas. Dengan bekal keterampilan mengelola sampah dan barang bekas, diharapkan para siswa menjadi kreatif dan produktif, hingga mampu meningkatkan daya saing dan taraf hidup yang lebih baik. Sedangkan strategi yang dilakukan yaitu dengan menghadirkan narasumber, trainer dan aktivis lingkungan untuk memberikan motivasi dan pemahaman yang benar tentang sampah dan barang bekas. Juga diberikan pengalaman langsung dalam bentuk praktek. Dengan metode ini, peserta mampu melakukan simulasi dan menerapkan apa yang telah dipelajari dari teori yang diberikan seperti bagaimana cara membuat tas dari bekas plastik bungkus Nutrisari dan membuat Bross dari botol plastik. Hasil kegiatan pelatihan pemanfaatan sampah dan barang bekas dapat meningkatkan kreativitas para santri, sekaligus menjadi usaha alternatif untuk meningkatkan ekonomi pondok.
\end{abstract}

Kata kunci: Sampah, barang bekas dan simulasi

\section{PENDAHULUAN}

Sistem pengelolaan sampah di provinsi Nusa Tenggara Barat dan di berbagai kabupaten dan kota, masih menghadapi permasalahan, mengingat besarnya timbunan sampah yang tidak sebanding dengan kapasitas penanganannya. Ini disebabkan kesadaran masyarakat yang masih rendah dalam penanganan sampah di tahap awal, juga keterbatasan fasilitas dan infrastruktur dalam pengangkutan sampah, serta pembinaan kesadaran masyarakat untuk membuang dan memanfaatkan sampah yang belum optimal. ${ }^{10}$

${ }^{10}$ Aisyah Odist, Mengelola Bank Sampah Bersistem Konvenional Berbasis Rumah Tangga, (Surabaya: Bee Media Nusanara, 2014), h. 11. 
Melihat fenomena sampah di atas, maka pelatihan keterampilan memanfaatkan barang bekas (sampah) adalah salah satu solusi yang melibatkan peran serta masyarakat dalam kegiatan menggalakkan program Bank Sampah yang berbasis rumah tangga dan pondok pesantren. Karena rumah tangga dan pondok pesantren, sesungguhnya adalah sumber utama penghasil sampah yang akan dibawa ke Tempat Pembuangan Sampah Sementara atau TPA.

Pengelolaan sampah, pada dasarnya mengacu pada Pertama, Undangundang nomor 18 tahun 2008 tentang Pengelolaan Sampah yang kemudian ditindaklanjuti dengan turunnya Peraturan Menteri Negara Lingkungan Hidup Republik Indonesia nomor 13 tahun 2012 tentang Pedoman Pelaksanaan Reduce, Reuse, Recycle melalui program Bank Sampah. Kedua, Penetapan Peraturan Gubernur Nusa Tenggara Barat tentang Pedoman Umum Pengembangan dan Pengelolaan Sampah Perkotaan, pasal $2 b$ dimana pengelolaan non fisik meliputi peningkatan kapasitas sumber daya manusia dalam masyarakat yang mencakup aspek tekhnis, manajmen dan peningkatan kesadaran (3R). ${ }^{11}$

Pengelolaan sampah juga merupakan salah satu usaha yang menjanjikan untuk meningkatkan ekonomi keluarga, pondok pesantren atau masyarakat yang memerlukan pendampingan, pelatihan dan kreatifitas. Melalui pengelolaan yang terstruktur dan berkesinambungan, dan dengan melakukan pelatihan-pelatihan, tentu dapat melahirkan Usaha Kecil Menengah (UKM) di pondok pesantren sebagai salah satu usaha ekonomi kreatif.

Usaha Kecil Menengah (UKM) merupakan salah satu bagian penting dari perekonomian negara Indonesia yang terdiri dari bebagai daerah baik provinsi maupun kabupaten/kota dengan potensi sumber daya manusia dan alam yang beragam. Berbagai usaha pengembangan UKM telah dilakukan, salah satunya dengan mengembangkan dan memperbanyak orang atau pengusaha baru di bidang UKM, sehingga elemen masyarakat diberi keterampilan dengan harapan, keterampilan tersebut menjadi usaha kreatif yang dapat memberi manfaat bagi peningkatan perekonomian pondok pesantren dan masyarakat.

Usaha kreatif tersebut juga dapat membuka kesempatan dan lapangan kerja baru bagi para santri dan pengasuh pondok pesantren. Hal ini senada seperti yang 13.

${ }^{11}$ Aisyah Odist, Mengelola Bank Sampah Bersistem Konvenional Berbasis Rumah Tangga, h. 
disampaikan oleh Kuncoro bahwa usaha kreatif di Indonesia telah memainkan peran penting dalam menyerap tenaga kerja dan mendukung peningkatan ekonomi dan pendapatan masyarakat. ${ }^{12}$

Pengabdian kepada masyarakat merupakan suatu media untuk menjembatani dunia pendidikan terutama perguruan tinggi dengan lembaga pendidikan, terutama madrasah-madrasah, di mana perguruan tinggi dihadapkan pada masalah bagaimana agar lembaga-lembaga tersebut, terutama madrasahmadrasah mampu menghadapi tantangan Masyarakat Ekonomi Asia (MEA) di era globalisasi dengan meningkatkan kreativitas dan produktivitas di bidang ekonomi.

Institut Agama Islam Negeri (IAIN) Mataram sebagai salah satu lembaga pendidikan harus mampu mengembangkan pola fikir dan kemampuan ummat/para santri, bukan hanya dalam konteks ilmu-ilmu agama, baik akidah, fikih dan akhlak, namun juga dalam konteks pengembangan ekonomi. Karena dalam konsep agama banyak terjadi penyimpangan karena permasalahan ekonomi, dan tidak jarang keterpurukan ekonomi menyebabkan seseorang mampu menjual akidah dan agamanya. Dalam sebuah hadis Rasululloh bersabda, "Kefakiran kadang bisa menyebabkan kekafiran". ${ }^{13}$

Pengabdian masyarakat dalam bentuk pendampingan dan pelatihan ini bertujuan untuk meningkatkan kualitas pendidikan Non Formal siswa dan siswi sebagai upaya peningkatan kualitas hidup. Meningkatkan pengetahuan bagi pengasuh dan kesadaran para santri/siswa-siswi tentang pentingnya keterampilan untuk bersaing di era globalisasi. Meningkatkan keterampilan siswa-siswi melalui penyediaan sarana keterampilan dan pelatihan untuk mengembangkan sikap kreatif dan kewirausahaan.

Dengan pelatihan keterampilan pengolahan bahan bekas dan potensi lokal, peserta pelatihan diharapkan mampu mengaplikasikannya baik dalam skala kecil maupun skala besar, sebagai home production (produksi rumahan) maupun usaha dalam skala besar. Dengan keterampilan ini peserta mampu bekerja lebih baik dan memperoleh pendapatan yang meningkat. Sehingga dengan adanya pelatihan ini,

12 Mudrajat Kuncoro, Perekonomian Indonesia, Ekonomi Pembangunan: teori, Masalah dan Kebijakan, (Yogyakarta: UPP. AMP, 2000), h. 3.

${ }_{13}$ M. Azrul Tanjung, et.al., Budaya Bisnis; Menuju Kebangkitan Ekonomi Ummat, (Jakarta: Dewan Pimpinan Majelis Ulama Indonesia, 2012), h. 150. 
pondok pesantren diharapkan mampu untuk berkontribusi untuk pengembangan ekonomi ummat.

\section{PEMBAHASAN}

Pengelolaan sampah di suatu tempat bertujuan untuk melayani sampah yang dihasilkan penduduknya, yang secara tidak langsung turut memelihara kesehatan masyarakat serta menciptakan suatu lingkungan yang bersih, baik dan sehat. Pada awalnya, pemukiman seperti pedesaan memiliki kepadatan penduduk yang masih sangat rendah. Secara alami tanah/alam masih dapat mengatasi pembuangan sampah yang dilakukan secara sederhana (gali urug). Makin padat penduduk suatu pemukiman atau kota dengan segala aktivitasnya, sampah tidak dapat lagi diselesaikan di tempat, sampah harus dibawa keluar dari lingkungan hunian atau lingkungan lainnya. Permasalahan sampah semakin perlu untuk dikelola secara profesional.

Saat ini pengelolaan persampahan menghadapi banyak tekanan terutama akibat semakin besarnya timbulkan sampah yang dihasilkan masyarakat baik produsen maupun konsumen. Hal ini menjadi semakin berat dengan adanya paradigma lama tentang pengelolaan sampah yang mengandalkan kegiatan pengumpulan, pengangkutan, dan pembuangan, dimana kegiatan ini membutuhkan anggaran yang semakin besar dari waktu ke waktu. Bila tidak tersedia akan menimbulkan banyak masalah operasional seperti sampah yang tidak terangkut, fasilitas yang tidak memenuhi syarat, cara pengoperasian fasilitas yang tidak mengikuti ketentuan teknis. Pada akhirnya, berbagai masalah tersebut akan bermuara pada rendahnya kuantitas dan kualitas pelayanan dan tidak diindahkannya perlindungan lingkungan dalam pengelolaan. Bila tidak segera dilakukan perbaikan, akan berdampak buruk terhadap kepercayaan dan kerjasama masyarakat yang sangat diperlukan untuk menunjang pelayanan publik yang menyejahterakan masyarakat.

Karena itu, untuk dapat mengelola sampah pemukiman atau kota yang sampahnya semakin banyak dan permasalahnnya yang kompleks, diperlukan adanya suatu sistem pengelolaan yang mencakup lembaga atau institusi yang dilengkapi dengan peraturan, pembiayaan/pendanaan dan peralatan penunjang, disamping meningkatkan kesadaran masyarakat terhadap sampah. 
Setiap hari berton-ton sampah di hasilkan dari pasar, rumah tangga, kegiatan pertanian dan industri. Bila timbunan sampah tidak dikelola dengan baik, maka berbagai masalah akan timbul. Di Indonesia, menurut data Kementerian Lingkungan Hidup $(\mathrm{KLH})$, rata-rata setiap penduduk Indonesia setiap hari menghasilkan 2 kilogram sampah, dengan asumsi volume sampah tahunan terus meningkat seiring bertambahnya jumlah penduduk. ${ }^{14}$

Data menunjukkan pada tahun 2010 jumlah sampah perhari adalah sebanyak 200.000 ton dan pada tahun 2012 sekitar 490.000 ton perhari, dimana 50\% dihasilkan dari sampah rumah tangga. $\mathrm{H}$ ini disebabkan karena sampah rumah tangga ternyata belum dikelola dengan baik. Baru hanya sekitar $24.5 \%$ sampah rumah tangga di Indonesia di tangani dengan metode yang benar, dengan diangkut petugas kebersihan dan dikelompokkan. Sisanya sekitar $75.5 \%$ belum tertangani dengan baik. ${ }^{15}$

Fakta ini diditunjukkan oleh data Riset Kesehatan Dasar (Riskerdes) tahun 2009 yang menyatakan bahwa rumah tangga di Indonesia menerapkan enam metode penanganan sampah, yaitu diangkut oleh petugas kebersihan $(23.4 \%)$, dikubur (4.2\%), dikomposkan (1.1\%), dibakar (52.1\%), dibuang keselokan/sungai/laut (9.2\%), dan dibuang sembarangan (9\%). ${ }^{16}$

$\mathrm{H}$ ini menunjukkan bahwa kesadaran masyarakat Indonesia masih rendah dalam pengelolaan sampah, termasuk sampah rumah tangga. Hal ini karena masyarakat sering kali mencari jalan pintas dan mudah dalam penanganan sampah, yaitu dengan membuang sampah di sungai atau membakarnya tanpa memikirkan dampak negatif yang ditimbulkan dari kebiasaan tersebut. Karena pembakaran sampah di tempat terbuka, akan menghasilkan gas beracun atau dioxin yang berasal dari pembakaran sampah plastik. Hal ini akan menyebabkan polusi udara, beberapa penyakit seperti; diare, kolera dan tifus yang disebabkan oleh virus yang berasal dari sampah yang mencari tanah dan mungkin diminum oleh manusia, terjadinya pemanasan global karena menghasilkan gas metan $(\mathrm{CH} 4)$ yang dapat merusak atmosfir bumi. Gas metan berada di atmosfir selama 7-9 tahun dan dapat meningkatkan suhu udara hingga 1.30 derajat selcius pertahun, Penyebab

\footnotetext{
${ }^{14}$ Aisyah Odist, Mengelola Bank Sampah ......h. 15-16.

15 Ibid., h. 11.

${ }^{16}$ Rilla Fustika, Dasar-dasar Sistem Pengelolaan Sampah, www. Sanitasi.net.
} 
terjadinya banjir, terlebih masyarakat yang tinggal di pinggiran sungai. Hal ini karena sampah yang dapat menyumbat aliran air sehingga menjebabkan banjir, Sampah juga dapat merusak pemandangan karena berserakan di pinggir jalan dan diberbagai objek wisata. Hal ini mengganggu potensi alam yang dimiliki karena tercemar oleh tumpukan sampah. ${ }^{17}$

Sampah plastik jika tercecer di tanah akan dapat merusak lingkungan, menghambat peresapan air, menyebabkan banjir dan merusak kesuburan tanah. Jika plastik terendam di laut, maka ekosistem laut pun bisa rusak. Banyak ditemukan binatang laut mati karena menelan sampah plastik. Tidak hanya itu, botol minuman kemasan yang digunakan lagi untuk isi ulang air minum, bisa berbahaya karena mengandung zat-zat yang membahayakan kesehatan. Belum lagi kerumitan yang dibutuhkan untuk membuat plastik. Setiap tahun dibutuhkan 12 juta barel minyak yang menghasilkan emisi gas rumah kaca yang cukup besar untuk membuat plastik, yaitu kantong plastik yang dibuat dari poleythene (PE) bahan thermoplastik. ${ }^{18}$

Plastik sendiri, jika pembakarannya tidak tuntas bisa menghasilkan karbondioksida yang dapat mencemari udara dan menjadi salah satu penyebab kanker pada manusia. Maka penting untuk mengetahui jenis plastik yang bisa digunakan kembali atau tidak melalui kode-kode yang tertera dalam kemasan plastik tersebut.

Di sisi lain, sampah memiliki manfaat, kalau seandainya setiap komponen bangsa sadar akan lingkungan di sekitarnya, mungkin permasalahan sampah yang tengah dihadapi oleh kota-kota besar khususnya, atau kita semua pada umumnya, tidak akan menjadikan momok yang menakutkan. Sebenarnya $\mathrm{h}$ ini dapat ditangani mulai dari lingkungan terkecil, yaitu keluarga dengan cara memanfaatkan sampah rumah tangga untuk dijadikan kompos.

Selama ini, sebagian besar rumah tangga dalam masyarakat masih memandang sampah sebagai barang sisa yang tidak berguna, bukan sebagai sumberdaya yang perlu dimanfaatkan. Paradigma baru memandang sampah sebagai sumber daya yang mempunyai nilai ekonomi dan dapat dimanfaatkan, misalnya untuk energi, kompos, pupuk ataupun untuk bahan baku industri.

${ }^{17}$ Aisyah Odist, Mengelola Bank Sampah Bersistem .......h. 16.

18 Muchlisin Riadi, Pengertian, Jenis dan Dampak Sampah, www.kajianpustaka.com. Lihat juga, Aisyah Odist, Mengelola Bank Sampah Bersistem Konvenional Berbasis Rumah Tangga, h. 11. 
Pengelolaan sampah dengan paradigma baru tersebut dilakukan dengan kegiatan pengurangan dan penanganan sampah. Masyarakat awam biasanya berpikir bahwa sampah rumah tangga yang dihasilkan tidak akan bermanfaat bagi mereka. Sampah yang dihasilkan dibiarkan menuju TPA (Tempat Pembuangan Akhir) tanpa menyadari bahwa sampah tersebut bisa sangat berguna bagi pendapatan mereka.

Dengan 3R atau pengolahan yang benar dan terlatih, mereka bisa mengolah sampah rumah tangga tadi menjadi usaha rumahan atau usaha kelompok masyarakat (UKM). Caranya yaitu dengan menerapkan sistem pemilahan sampah organik dan anorganik dengan membuat tempat sampah yang khusus untuk sampah organik dan anorganik pada setiap rumah warga. Dengan terlebih dahulu menyampaikan apa saja jenis sampah organik dan anorganik rumah tangga.

Penerapan sistem 3R dalam rumah tangga bisa menjadi pola hidup peduli lingkungan dan diterapkan pada setiap orang yaitu: Pertama, Reduce atau mengurangi sampah dengan mengurangi pemakaian barang atau benda yang tidak terlalu kita butuhkan, misalnya dengan mengurangi pemakaian kantong plastik. Biasanya, sampah rumah tangga yang paling sering dijumpai adalah sampah dari kantong plastik yang dipakai sekali lalu dibuang. Padah, plastik adalah sampah yang perlu ratusan tahun (200-300 tahun) untuk terurai kembali.

Kedua, Reuse atau memakai dan memanfaatkan kembali barang-barang yang sudah tidak terpakai menjadi sesuatu yang baru. Sampah rumah tangga yang bisa digunakan untuk dimanfaatkan seperti koran bekas, kardus bekas susu, kaleng susu, wadah sabun lulur, dan lain-lain. Barang-barang tersebut dapat dimanfaatkan sebaik mungkin misalnya diolah menjadi tempat untuk menyimpan tusuk gigi atau cottonbut. Selain itu barang-barang bekas tersebut dapat dimanfaatkan oleh anakanak, misalnya memanfaatkan buku tulis lama jika masih ada lembaran yang kosong bisa dipergunakan untuk corat coret, buku-buku cerita lama dikumpulkan untuk perpustakaan mini di rumah untuk mereka dan anak-anak sekitar rumah. Itu juga salah satu cara pemanfaatan sampah rumah tangga.

Ketiga, Recycle yaitu mendaur ulang kembali barang lama menjadi barang baru. Sampah organik bisa dimanfaatkan sebagai pupuk dan sampah anorganik bisa didaur ulang menjadi sesuatu yang bisa digunakan kembali seperti mendaur ulang kertas yang tidak digunakan menjadi kertas kembali, botol plastik bisa didaur ulang 
menjadi tempat alat tulis, sedangkan plastik detergen, kopi, susu, bisa dijadikan tas cantik, dompet, dan lain-lain. ${ }^{19}$

Sampah anorganik bisa diolah dengan proses daur ulang. Daur ulang mempunyai pengertian sebagai proses menjadikan bahan bekas atau sampah menjadi bahan baru yang dapat digunakan kembali. Dengan proses daur ulang, sampah dapat menjadi sesuatu yang berguna sehingga bermanfaat untuk mengurangi penggunaan bahan baku yang baru. Manfaat lainnya adalah menghemat energi, mengurangi polusi, mengurang kerusakan lahan dan emisi gas rumah kaca dari pada proses pembuat barang baru.

Proses daur ulang rumah tangga dengan memilah, yakni mengelompokkan sampah rumah tangga yang berdasarkan jenisnya dengan membuat tempat sampah anorganik dan organik, seperti kaca, kertas, plastik, sayur-sayuran, sesuai jenisnya. Setelah dipilah, carilah barang yang masih bisa digunakan kembali secara langsung. Bersihkan terlebih dahulu sebelum digunakan. Dengan kreatifitas dan pelatihan, berbagai sampah yang telah terkumpul dan dipilah, dapat disulap menjadi barang-barang baru yang bermanfaat. Sedangkan sampah organik rumah tangga yang dihasilkan bisa dimanfaatkan menjadi kompos untuk bahan pupuk tanaman dan pertanian.

Dengan menerapkan sistem 3R dalam pengelolaan sampah rumah tangga, bisa berdampak positif bagi lingkungan. Bukan saja lingkungan rumah tangga, tetapi juga bagi lingkungan sekitar. Apalagi maraknya isu global warming yang sudah menjadi masalah dunia yang harus kita selsaikan bersama. Oleh karena itu banyak sekali manfaat yang dihasilkan dari sistem 3R terhadap sampah rumah tangga. Karena sampah tidak selalu akan menjadi barang sisa yang tidak bermanfaat bagi manusia Apabila kita mau menjaga lingkungan sekitar.

Pondok pesantren sebagai lembaga pendidikan dan kaderisasi umara, ulama dan cendikiawan, memiliki tanggungjawab besar dalam meningkatkan ekonomi ummat sebagai modal sosial. Berikut mendorong tata kelola yang berintegritas, kredibilitas, profesionalitas dan akuntabilitas sebagai bagian dari karakter pondok. Karena itu, salah satu yang diperlukan adalah adanya lembaga/unit usaha

${ }^{19}$ Aisyah Odist, Mengelola Bank Sampah Bersistem ......h. 15-16. 
pengembangan ekonomi pondok yang berbasis inovasi dan kreatifitas, supaya potensi pondok dapat dimanfaatkan secara maksimal.

Berdasarkan hasil observasi di pondok pesantren Madrasatul Qur'aniyyah Senteluk Lombok Barat, ternyata masih banyak tumpukan sampah dan barang bekas yang tidak dimanfaatkan. Di satu sisi, lingkungan pondok terlihat kurang bersih, karena berbagai macam sampah tersebut mengeluarkan bau yang kurang sedap, bahkan mengganggu pandangan mata. Di sisi yang lain, tumpukantumpukan sampah tersebut sebenarnya masih bisa dimanfaatkan dan dapat bernilai ekonomis, jika saja para pengasuh dan siswa-siswa memiliki kapabilitas dan kreatifitas untuk mengolahnya menjadi barang-barang yang dapat difungsikan kembali, seperti tas dan kompos.

Alasan utama untuk memilih pondok pesantren Madrasatul Qur'aniyyah sebagai madrasah binaan; pertama, karena madrasah ini merupakan salah satu lembaga pendidikan yang berbasis Islam. Kedua, Islam mengajarkan tentang pentingnya menjaga kebersihan, namun dalam realitasnya sering terjadi paradoks antara nilai dan kenyataan. Ketiga, Pondok pesantren Madrasatul Qur'aniyyah memiliki santri yang berasrama berjumlah ratusan. Tentu mereka memiliki sampah sehari-hari yang berasal dari makanan maupun minuman. Keempat, di pondok pesantren ini belum pernah dilakukan pelatihan tentang pengelolaan sampah dan barang bekas.

Dari permasalahan yang ada dan melihat kenyataan banyaknya sampah yang tidak dimanfaatkan dan kurangnya kesadaran santri-santri untuk menjaga kebersihan lingkungan serta rendahnya pengetahuan tentang pemanfaatan sampah dan barang bekas, disebabkan salah satunya, karena mereka tidak memiliki keterampilan atau kreativitas dalam mengolah potensi-potensi barang bekas disekitar mereka serta sampah lokal yang mereka miliki, seperti serabut kelapa, lidi kelapa dan beberapa barang bekas kayu yang sesungguhnya dapat bernilai ekonomis, dan dapat dijadikan sebagai salah satu penghasil kerajinan atau keterampilan tertentu. Keterampilan tersebut tentu akan mampu mereka kembangkan, jika saja mereka dapat mengikuti kursus-kursus atau pelatihan keterampilan mengelola barang-barang bekas, seperti kayu, kaleng bekas dan lainlain. 
Namun untuk mendapatkan keterampilan dan kreatifitas dalam $\mathrm{h}$ mengolah potensi lokal memerlukan pelatihan-pelatihan atau kursus-kursus dengan biaya tertentu. Tentu saja, $\mathrm{h}$ tersebut berat bagi pengasuh dan santri-santri yang minim pendanaan. Karena itu, perlu ada lembaga atau instansi pemerintah yang memfasilitasi pelatihan-pelatihan dan memberikan pendampingan. Dengan adanya pelatihan-pelatihan tersebut dapat membantu pengasuh pondok dan siswa-siswa untuk dapat mengelola potensi lokal yang mereka miliki, sehingga paling tidak, dapat mengangkat perekonomian dan mengurangi pengangguran.

Karena itu, pendampingan dan pelatihan diberikan sebagai upaya untuk meningkatkan kemampuan para pengasuh dan santri-santri dalam menghadapi tuntutan maupun perubahan lingkungan sekitarnya. Pemberian pelatihan bagi para santri/siswa bertujuan untuk memberdayakan para pengasuh dan santri-santri, sehingga pondok pesantren menjadi berdaya dan dapat berpartisipasi aktif pada proses perubahan. Pelatihan dapat membantu pengasuh dan siswa untuk menerapkan ilmu pengetahuan dan kemampuan yang telah dimiliki. Dengan pelatihan juga dapat menimbulkan perubahan dalam kebiasaan-kebiasaan bekerja, perubahan sikap terhadap pekerjaan, serta dalam informasi dan pengetahuan yang mereka terapkan dalam pekerjaannya sehari-hari. Kegiatan pelatihan dapat terjadi apabila seseorang atau masyarakat menyadari perlunya mengembangkan potensi dan kemampuan dalam memenuhi kebutuhan maupun kepuasan hidupnya. Oleh sebab itu, diperlukan kegiatan pengabdian dalam bentuk pendampingan, pelatihan dan pemberdayaan masyarakat sebagai bentuk pengembangan potensi kreatifitas dan sumber daya manusia.

\section{Agama dan Pemberdayaan Ekonomi Kreatif}

Dalam pelaksanaan pengabdian ini, para pengasuh dan siswa-siswi Madrasatul Qur'aniyyah kami bekali dengan berbagai nilai-nilai dan doktrin agama sebagai dasar untuk melangkah, karena dalam perspektif agama Islam, apapun yang kita lakukan jika didasari karena ibadah, maka akan bernilai ibadah dan seharusnya mampu untuk meningkatkan kesadaran masyarakat tentang hidup. Sesi ini mengupas berbagai kondisi sosial masyarakat dan dinamika kehidupan masyarakat serta tantangan yang dihadapai saat ini seperti kemiskinan, kebodohan dan lain-lain. 
Kemiskinan memang menjadi masalah besar bagi bangsa Indonesia. Pada bulan Maret 2011 saja jumlah penduduk miskin sebanyak 30,02 juta jiwa atau sekitar 12,49 persen. Sedangkan pada bulan Maret 2012 turun menjadi 29,13 juta jiwa atau sekitar 11,96 persen. Memang, setelah krisis ekonomi pada 1998, pemerintah menggelar berbagai program untuk menanggulangi kemiskinan, diantaranya program Jaring Pengaman Sosial (JPS), penjualan beras untuk orang miskin (raskin), subsidi BBM untuk pendidikan dan kesehatan. Namun, kemampuan anggaran pemerintah terbatas. Karena dana pemerintah terbatas, apalagi sebagian dana bantuan itu disunat atau tidak sampai ke sasaran, maka perlu adanya penggalangan dana dari masyarakat dengan memberdayakan ekonomi umat melalui pengelolaan lembaga-lembaga keuangan syari'ah, wakaf produktif, zakat dan lain-lain.

Pengembangan dan pemberdayaan ekonomi dalam Islam mengindikasikan bahwa perhatian Islam terhadap bidang ekonomi merupakan bagian dari syariah dan yang menjadi tuntutan dalam upaya pemeliharaan sumber-sumber ekonomi dan pengembangannya, meningkatkan kemampuan produksi dengan mengembangkan sistem dan metodenya, dan h-h lain yang menjadi tuntutan dalam merealisasikan kesejahteraan ekonomi umat, memenuhi kebutuhan yang mendasar, dan memerangi kemiskinan. Dalam $\mathrm{h}$ ini, tentu peranan para ulama terutama MUI dan BAZNAS NTB dalam meyakinkan orang-orang Islam yang berkecukupan materi sangat penting, supaya mereka mau menyalurkan dananya untuk membangun ekonomi ummat sebagai ibadah dan wujud kesalehan sosial mereka. Saat ini, sekitar sepuluh juta orang menganggur dan tiga puluh juta orang lainnya miskin di Indonesia.

Sebagai kelompok mayoritas di Indonesia, ummat Islam memiliki tanggungjawab besar dalam meningkatkan modal sosial yang mulai luntur itu dengan mendorong integritas, kredibilitas, profesionalitas dan akuntabilitas menjadi bagian dari karakter mereka sehingga kepercayaan di masyarakat terbangun. Karena itu, salah satu yang diperlukan adalah adanya lembaga-lembaga keuangan yang dijalankan secara profesional dan akuntabel supaya potensi dana ummat yang besar itu dapat didayagunakan. Lembaga-lembaga keislaman di Indonesia pun sudah saatnya dikelola secara profesional untuk bisa meningkatkan kepercayaan umat. 
Namun, anggaran pemerintah terbatas, apalagi sebagian dana bantuan itu disunat atau tidak sampai ke sasaran serta Trust yang minim di masyarakat, karena masih kuatnya praduga dan ketakutan akan korupsi dan penyalahgunaan wewenang, menyulitkan pemberdayaan modal ummat untuk mendukung dana bergulir bagi usaha-usaha kecil produktif.

Maka dibutuhkan dalam masyarakat Islam kreativitas yang tinggi dalam rangka meningkatkan daya saing dan tarap hidupnya. Kreativias melahirkan alternatif-alternatif sehingga masyarakat dapat memanfaatkan apa saja bahkan dari sesuatu yang dianggap sampah atau tidak bernilai.

Sedangkan pada sesi kedua disampaikan beberapa $\mathrm{h}$ yang terkait dengan pengelolaan barang bekas atau sampah.

\section{Pengelolaan Sampah dan Barang Bekas}

Dalam pengelolaan barang bekas ada beberpa landasan atau pilar yang harus dipenuhi;

1. Pilar sosialisasi (Teori)

Pilar sosialisasi fokus pada sosialisasi atau pengenalan kepada masyarakat untuk mempraktekkan kegiatan 3R (Reuse, Reduce dan recycle) dalam kehidupan sehari-hari. Kegiatan $3 \mathrm{R}$ dapat dilakukan oleh siapa saja dan dimana saja serta tidak membutuhkan biaya yang besar. Meskipun demikian, kegiatan $3 \mathrm{R}$ yang sederhana dapat memberikan dampak yang signifikan, membantu bumi untuk menghemat energi, menghemat matrial produk, mengurangi sampah di tempat penimbunan sampah dan menjaga kelestarian lingkungan. Berikut ini adalah contoh kegiatan 3R:

a. Reuse. Reuse adalah kegiatan untuk menggunakan kembali wadah atau kemasan seperti;

- Memilih wadah, kantong atau benda yang dapat digunakan beberapa kali atau berulang-ulang. Misalnya, memilih menggunakan serbet dari kain dari pada tissu dan menggunakan batrei yang dapat dicharge kembali.

- Menggunakan kembali wadah atau kemasan yang telah kosong untuk fungsi yang sama atau fungsi lainnya.

- Menggunakan alat-alat elektronik yang bisa dihapus atau dan ditulis kembali, misalnya alat perekam digital. 
- Menggunakan sisi kertas yang masih kosong

b. Reduce. Reduce adalah suatu kegiatan yang mengurang sampah plastik, misalnya;

- Memilih produk dengan kemasan daur ulang

- Menghindari membeli atau menggunakan produk yang menghasilkan sampah dalam jumlah yang besar.

- Menggunakan produk yang bisa diisi ulang (refill)

- Menghindari penggunaan barang sekali pakai.

- Menghindari memakai atau membeli barang-barang yang kurang perlu.

- Menggunakan email untuk mengirim pesan.

- Menjual atau memberikan sampah yang terpilah kepada pihak yang memerlukan

c. Recycle. Yang dimaksud dengan recycle adalah kegiatan mendaur ulang kembali sampah plastik menjadi benda-benda yang bisa dipergunakan kembali, seperti;

- Memilih produk yang mudah didaur ulang dan terurai.

- Melakukan pengolahan sampah organik menjadi kompos.

- Melakukan pengolahan sampah anorganik menjadi barang bermanfaat.

2. Pilar Pelatihan (Praktik)

Pilar pelatihan adalah pilar yang memfokuskan pada pelatihan kader dan masyarakat yang akan menjadi tenaga pengajar untuk pendampingan. Pilar ini sangat mendukung kegiatan yang dilakukan oleh Bank Sampah. Diantaranya adalah untuk menigkatkan sumber daya manusia dan mensinergikan potensi mayarakat. Melalui pelatihan, maka komunikasi akan terjalin baik antara masyarakat dan Bank Sampah sebagai penyedia stok kerajinan siap jual.

Pilar Kontribusi. Pilar kontribusi adalah pilar yang memiliki tujuan untuk memberikan dampak positif barang bekas kepada masyarakat.

Pilar Pemasaran dan Kerjasama. Pilar ini bertujuan utuk menjalin kerjasama dengan berbagai pihak seperti Lembaga Swadaya Masyarakat (LSM), pemerintah dan masyarakat secara umum. Pilar ini menjadi penting dalam rangka memperkenalkan dan sekaligus memasarkan hasil kerajinan masyarakat yang berasal dari barang bekas atau sampah. Dalam $\mathrm{h}$ ini mengikuti bebagai 
event dan pameran untuk memperkenalkan produk yang sudah dibuat, sekaligus menjadi ajang sosialisasi kepada masyarakat luas dan berkesempatan untuk bertemu dengan pembeli untuk pemasaran yang lebih luas.

3. Praktek Membuat Tas dari Bungkus Nutrisi

a. Alat dan Bahan yang diperlukan:

1) Bungkus nutrisari/snack atau sejenisnya

2) Gunting

3) Jarum dan benang

b. Langkah-langkah:

1) Bungkus nutrisi yang telah dicuci diukur dan digunting dengan pola yang sama.

2) Lipat dalam bentuk yang sama

3) lipat dan anyam dengan pola dasar huruf $T$

4) Lipat dan paskan kedua sisinya dan lakukan $\mathrm{h}$ yang sama pada sisi sebaliknya.

5) Lalukan proses yang sama sehingga terbentuk pola.

4. Membuat Bross dari Botol Plastik

a. Alat dan Bahan yang Diperlukan:

1) Botol Plastik

2) Cutter/Gunting

3) Lem

4) Solder

5) Kancing Bross

b. Langkah-langkah:

1) Potong bagian bawah botol

2) Bentuk seperti bunga

3) Bentuk tiap sisinya dengan solder

4) Beri lem pada bagian belakang dan lekatkan kancing bross. 
Transformasi, Vol. 12, No. 2, Juli 2016: 134-148

\section{KESIMPULAN}

Dari pelatihan tentang peningkatan ekonomi ummat melalui pemanfaatan sampah dan barang bekas di pondok pesantren Mdrasatul Qur'aniyyah desa Senteluk Lombok Barat dapat disimpulkan bahwa kegiatan pelatihan pemanfaatan sampah dan barang bekas dapat meningkatkan kreativitas para santri, sekaligus menjadi usaha alternatif untuk meningkatkan ekonomi pondok.

\section{DAFTAR PUSTAKA}

Kuncoro, Mudrajat, Perekonomian Indonesia, Ekonomi Pembangunan: Teori, Masalah dan Kebijakan, Yogyakarta: UPP. AMP, 2000.

Kropotkin, Peter, alih bahasa; Tim Redaksi Pramedia, Gotong Royong Kunci Kesejahteraan Sosial, Jakarta: PT. Piramedia, 2006.

Odist, Aisyah, Mengelola Bank Sampah; Bersistem Konvensional Berbass Rumah tangga, Mataram: Bee Media Nusantara, 2014.

Riadi, Muchlisin, Pengertian, Jenis dan Dampak Sampah, www.kajianpustaka.com

Tanjung, M. Azrul, et.al., Budaya Bisnis; Menuju Kebangkitan Ekonomi Ummat, Jakarta: Dewan Pimpinan Majelis Ulama Indonesia, 2012.

Badan Pusat Statistik Kabupaten Lombok Barat, Lombok Barat Dalam Angka, Lombok Barat: Badan Pusat Statistik Kabupaten Lombok Barat, 2012

Kementerian Lingkungan Hidup, Buku Panduan Satuan Karya Pramuka Saka Kalpataru, Kementerian Lingkungan Hidup, 2013. 